\title{
Comparison of Thin-layer Chromatography, Spectrofluorimetry and Bright Greenish-yellow Fluorescence Test for Aflatoxin Detection in Corn
}

\author{
Elisabete Yurie Sataque Ono ${ }^{1 *}$, Marcelo da Silva ${ }^{1}$, Ricardo Marcelo Reche Ribeiro ${ }^{2}$, Mario \\ Augusto Ono $^{3}$, Luciana Hayashi ${ }^{2}$, Glauco Tironi Garcia ${ }^{4}$ and Elisa Yoko Hirooka ${ }^{2}$ \\ ${ }^{1}$ Departamento de Bioquímica e Biotecnologia; Universidade Estadual de Londrina; C. P.: 6001; 86051-980; \\ Londrina - PR - Brasil. ${ }^{2}$ Departamento de Ciência e Tecnologia de Alimentos; C. P.: 6001; 86051-980; Londrina - \\ PR - Brasil. ${ }^{3}$ Departamento de Ciências Patológicas; Universidade Estadual de Londrina; C. P.: 6001; 86051-98; \\ Londrina - PR - Brasil. ${ }^{4}$ Integrada Cooperativa Agroindustrial; 86380-000; Andirá - PR - Brasil
}

\begin{abstract}
In this study the bright greenish-yellow fluorescence test, widely used by the corn milling industry, was compared to the thin-layer chromatography (TLC) and spectrofluorimetry methods for aflatoxin detection in 40 corn samples naturally contaminated by the Aspergillus section Flavi. According to the corn processing industry criteria, all the samples were adequate for human and animal consumption by the bright greenish-yellow fluorescence test, but TLC and spectrofluorimetry analysis detected aflatoxins above the maximum tolerated limit $(20 \mu \mathrm{g} / \mathrm{kg})$ in 7 and 8 samples, respectively. Aflatoxins were detected in 16 (40\%) corn samples by TLC, with levels ranging from 4.0 to $54.0 \mu \mathrm{g} / \mathrm{kg}$ (mean $19.97 \pm 15.97 \mu \mathrm{g} / \mathrm{kg}$ ), and in 25 (62.5\%) samples by spectrofluorimetry, with levels ranging from 1.0 to $58.66 \mu \mathrm{g} / \mathrm{kg}$ (mean $17.14 \pm 17.81 \mu \mathrm{g} / \mathrm{kg}$ ). The results indicated a good correlation $(\rho=0.97)$ between TLC and spectrofluorimetry for aflatoxin determination in naturally contaminated corn. The bright greenish-yellow fluorescence test was simple and quick, but it showed 20\% false-negative results, suggesting its use only as screening method for detecting the suspected lots of grains that should be tested further for aflatoxin by more sensitive methods.
\end{abstract}

Key words: Thin-Layer Chromatography; spectrofluorimetry; BGYF; aflatoxins; corn; mycotoxins

\section{INTRODUCTION}

Aflatoxins are toxic secondary metabolites produced mainly by Aspergillus flavus and $A$. parasiticus. Aflatoxins $\mathrm{B}_{1}\left(\mathrm{AFB}_{1}\right), \mathrm{B}_{2}\left(\mathrm{AFB}_{2}\right), \mathrm{G}_{1}$ $\left(\mathrm{AFG}_{1}\right)$ and $\mathrm{G}_{2}\left(\mathrm{AFG}_{2}\right)$ have been detected in corn (Hussein and Brasel, 2001), although $\mathrm{AFB}_{1}$ is the most frequent and toxic, causing risks to human health due to its carcinogenic, mutagenic and teratogenic effects (WHO, 1979). In addition to the health hazard, the natural occurrence of aflatoxins in agricultural staples causes serious economic losses for commercial sectors including crop, livestock and poultry producers, as well as

*Author for correspondence: eysono@uel.br 
food and feed processors. Losses may result from poor grain quality, low crop yields, crop downgrading and reduced animal performance (Pestka et al., 1995).

Taking into account that mycotoxin is a problem difficult to avoid and that more and more strict guidelines on mycotoxin contamination have been imposed by the importing countries, the most effective control measure depends on a rigorous program of monitoring the food and feed producing chain. Therefore, sensitive and accurate methods for mycotoxin detection are essential to minimize the exposure and comply with trade requirements. Conventional aflatoxin detection techniques include thin-layer chromatography (TLC), high-performance liquid chromatography (HPLC), gas-liquid chromatography, and mass spectroscopy (Pestka et al., 1995). These methods are accurate and reproducible, but require extensive clean-up steps to overcome the food matrix interferences, trained staff and a timeconsuming procedure, in addition to high cost and use of harmful solvents (Barna-Vetró et al., 1996; Sydenham et al., 1996a, b).

The corn milling industry has widely used the presence of bright greenish-yellow fluorescence under an ultraviolet (UV) light as a presumptive indicator of aflatoxin. This method is not quantitative, nor is it a direct detection of aflatoxin itself because the fluorescence is produced by the oxidative action of peroxidases in living plant tissue on kojic acid, which is formed with aflatoxin by A. flavus (Marsh et al., 1969). The aim of this study was to evaluate the performance of the bright greenish-yellow fluorescence test and compare it to TLC and spectrofluorimetry for aflatoxin detection in corn samples.

\section{MATERIALS AND METHODS}

\section{Corn samples}

Out of 400 freshly harvested corn (Zea mays L.) samples collected from three processing industries in the Northern region of Paraná State (2003 crop), 40 samples were selected based on their positivity for the Aspergillus section Flavi. Corn kernels were taken randomly from 9 to 12 truck bin sites immediately after harvesting and pooled $(10 \mathrm{~kg})$, following the sampling protocol established by the Brazilian Guidelines (Brasil, 1976). After homogenization, the corn samples $(1 \mathrm{~kg})$ were sent to the laboratory and maintained at $4{ }^{\circ} \mathrm{C}$ for a maximum of 7 days for microbiological analysis. For aflatoxin determination, $200 \mathrm{~g}$ of each corn sample were ground to 20 mesh and stored at $-20^{\circ} \mathrm{C}$.

\section{Mycoflora analysis}

Mycoflora analysis was carried out as described by Ono et al. (2006).

\section{Bright greenish-yellow fluorescence test}

An aliquot of $100 \mathrm{~g}$ sample was ground and analyzed under UV light (365 $\mathrm{nm})$. The number of bright greenish-yellow fluorescence (BGYF) points was counted and samples with three or more points were considered suspect for aflatoxin contamination.

\section{Aflatoxin determination by Thin-Layer Chromatography}

The aflatoxin extraction was carried out according to Soares and Rodriguez-Amaya (1989). An aliquot of $50 \mathrm{~g}$ sample, previously ground to 20 mesh, was extracted with methanol $-4 \% \mathrm{KCl}$, cleaned up with ammonium sulfate $30 \%$ and diatomaceous earth followed by two partitions to chloroform. Aliquots of $5 \mathrm{~mL}$ each of first and second chloroform extractions were combined and evaporated to dryness in an $80^{\circ} \mathrm{C}$ water bath. The residue was dissolved in $200 \mu \mathrm{L}$ chloroform and aflatoxins were analyzed using silica gel G 60 plates (Merck, Darmstadt, GFR) and toluene:ethyl acetate: chloroform:formic acid (70:50:50:20, v/v) as developing solvent according to Gimeno (1979). The mean recovery rates from spiked corn in the range $5-20 \mu \mathrm{g} / \mathrm{kg}$ were $97 \%$ for $\mathrm{AFB}_{1}$, 93\% for $\mathrm{AFG}_{1}, 93 \%$ for $\mathrm{AFB}_{2}$ and $94 \%$ for $\mathrm{AFG}_{2}$ (mean $\mathrm{CV} 8.3 \%$ ) based on duplicate spiking and analyses. The detection limit was $4 \mu \mathrm{g} / \mathrm{kg}$. All the samples were analyzed in duplicate.

\section{Aflatoxin determination by spectrofluorimetry} An aliquot of $50 \mathrm{~g}$ sample, previously ground to 20 mesh, was mixed with $5 \mathrm{~g} \mathrm{NaCl}$ and $100 \mathrm{~mL}$ methanol:water $(80: 20, \mathrm{v} / \mathrm{v})$ and blended at high speed for $3 \mathrm{~min}$. After filtration, $10 \mathrm{~mL}$ extract were diluted with $40 \mathrm{~mL}$ ultra-pure water and 5 $\mathrm{mL}$ were cleaned up using Aflatest- $\mathrm{P}^{\circledR}$ immunoaffinity column (Vicam, Somerville, MA). After washing the column with $10 \mathrm{~mL}$ ultra-pure water, aflatoxins were eluted with $1 \mathrm{~mL}$ methanol. Quantification was performed by spectrofluorimetry (Cary Eclipse, Varian) adding $1 \mathrm{ml}$ developing solution $(0.003 \%$ bromine $)$. 
Excitation and emission wavelengths were $363 \mathrm{~nm}$ and $440 \mathrm{~nm}$, respectively. The mean recovery rates from spiked corn in 5 and $30 \mu \mathrm{g} / \mathrm{kg}$ were 72.4 and $80 \%$ (mean CV 8.8\%), respectively, based on duplicate spiking and triplicate analyses. Detection limit was $1.0 \mu \mathrm{g} / \mathrm{kg}$. All the samples were analyzed in triplicate.

\section{Statistical analysis}

Aflatoxin levels detected by TLC were compared to spectrofluorimetry analysis using the Pearson correlation test (Statistic software 6.0, Stat Soft, Inc.).

\section{RESULTS AND DISCUSSION}

The number of bright greenish-yellow fluorescence points, Aspergillus section Flavi count and aflatoxin levels in 40 corn samples are shown in Table 1.

Table 1 - Aspergillus section Flavi count, number of bright greenish-yellow fluorescence (BGYF) points and aflatoxin levels determined by thin-layer chromatography (TLC) and spectrofluorimetry

\begin{tabular}{|c|c|c|c|c|}
\hline \multirow{2}{*}{ Samples } & \multicolumn{2}{|c|}{ Aflatoxins } & \multirow{2}{*}{$\begin{array}{l}\text { Aspergillus section } \\
\text { Flavi (CFU/g) }\end{array}$} & \multirow{2}{*}{$\begin{array}{l}\text { Number of } \\
\text { BGYF points }\end{array}$} \\
\hline & TLC ( $\mu \mathrm{g} / \mathrm{kg})$ & Spectrofluorimetry $(\mu \mathrm{g} / \mathrm{kg})$ & & \\
\hline 1 & 4.00 & 5.64 & $1.0 \times 10^{2}$ & 1 \\
\hline 2 & 32.00 & 41.12 & $1.0 \times 10^{2}$ & 1 \\
\hline 3 & 4.50 & 10.23 & $1.0 \times 10^{2}$ & 1 \\
\hline 4 & 4.00 & 12.75 & $1.5 \times 10^{2}$ & 1 \\
\hline 5 & ND & ND & $3.0 \times 10^{3}$ & 2 \\
\hline 6 & ND & ND & $1.0 \times 10^{2}$ & 1 \\
\hline 7 & ND & 2.16 & $1.0 \times 10^{2}$ & 1 \\
\hline 8 & 5.50 & 9.97 & $1.0 \times 10^{4}$ & 1 \\
\hline 9 & ND & ND & $1.0 \times 10^{2}$ & ND \\
\hline 10 & 10.50 & 16.18 & $5.5 \times 10^{3}$ & 1 \\
\hline 11 & ND & 1.72 & $2.0 \times 10^{2}$ & ND \\
\hline 12 & ND & 1.44 & $1.0 \times 10^{2}$ & 1 \\
\hline 13 & ND & 1.22 & $1.0 \times 10^{2}$ & 1 \\
\hline 14 & 54.00 & 58.66 & $1.0 \times 10^{4}$ & 1 \\
\hline 15 & ND & ND & $1.0 \times 10^{2}$ & 1 \\
\hline 16 & ND & ND & $1.5 \times 10^{2}$ & ND \\
\hline 17 & ND & 1.00 & $1.0 \times 10^{2}$ & ND \\
\hline 18 & 27.00 & 34.70 & $1.0 \times 10^{2}$ & 1 \\
\hline 19 & ND & 1.50 & $1.0 \times 10^{2}$ & ND \\
\hline 20 & 5.00 & 9.26 & $1.0 \times 10^{3}$ & 1 \\
\hline 21 & ND & 1.30 & $1.5 \times 10^{3}$ & 1 \\
\hline 22 & 38.00 & 42.55 & $1.0 \times 10^{3}$ & 1 \\
\hline 23 & ND & ND & $1.0 \times 10^{3}$ & 1 \\
\hline 24 & ND & ND & $5.0 \times 10^{2}$ & 1 \\
\hline 25 & 20.00 & 25.29 & $1.0 \times 10^{3}$ & 1 \\
\hline 26 & ND & ND & $5.0 \times 10^{2}$ & 1 \\
\hline 27 & ND & 1.15 & $1.0 \times 10^{3}$ & 1 \\
\hline 28 & 45.00 & 49.67 & $1.0 \times 10^{4}$ & 1 \\
\hline 29 & ND & ND & $1.0 \times 10^{3}$ & 1 \\
\hline 30 & ND & 1.38 & $1.0 \times 10^{2}$ & 1 \\
\hline 31 & ND & ND & $1.0 \times 10^{2}$ & 1 \\
\hline 32 & ND & ND & $5.0 \times 10^{2}$ & 1 \\
\hline 33 & 10.00 & 14.01 & $1.0 \times 10^{2}$ & 1 \\
\hline 34 & ND & ND & $1.0 \times 10^{2}$ & 1 \\
\hline 35 & ND & ND & $1.0 \times 10^{2}$ & 1 \\
\hline 36 & 10.00 & 15.39 & $5.0 \times 10^{3}$ & 1 \\
\hline 37 & 25.00 & 30.23 & $1.0 \times 10^{4}$ & 2 \\
\hline 38 & 25.00 & 39.87 & $4.5 \times 10^{3}$ & 1 \\
\hline 39 & ND & ND & $1.0 \times 10^{3}$ & 1 \\
\hline 40 & ND & ND & $4.0 \times 10^{2}$ & 1 \\
\hline
\end{tabular}

$\mathrm{ND}=$ not detected

Detection limit: $\mathrm{TLC}=4 \mu \mathrm{g} / \mathrm{Kg}$; Spectrofluorimetry $=1 \mu \mathrm{g} / \mathrm{Kg}$ 
The samples selected for the comparison of different methods were positive for the Aspergillus section Flavi, ranging from $1.0 \times 10^{2}$ to $1.0 \times 10^{4}$ CFU/g corn. A total of 33 samples (82.5\%) showed one point of fluorescence, two samples (5\%) two points and in five samples $(12.5 \%)$ no fluorescent point was detected by the bright greenish-yellow fluorescence test. According to the corn processing industry criteria, all the samples were adequate for human and animal consumption. These results were not in accordance with TLC and spectrofluorimetry analysis which detected aflatoxins above the maximum tolerated limit $(20 \mu \mathrm{g} / \mathrm{kg})$ in 7 and 8 samples, respectively, i.e., the bright greenish-yellow fluorescence test showed false negative results. Glória et al. (1998) reported 14 false-negative results out of 286 corn samples analyzed by the bright greenish-yellow fluorescence test, when compared to TLC whose contamination levels were $>20 \mu \mathrm{g} / \mathrm{kg}$. Palomino et al. (1998) analyzed 61 corn samples by the bright greenish-yellow fluorescence test and detected two false-negative samples (3\%) in comparison to TLC.

Out of 40 corn samples analyzed, five samples $(12.5 \%)$ did not show fluorescent points under UV light, although they were contaminated by Aspergillus section Flavi and/or aflatoxins (Table 1). Thompson and Henke (2000) reported no relationship between the number and weight of fluorescing corn kernels and aflatoxin levels. Interfering compounds in corn matrix, when excited by UV light can absorb and emit fluorescent light with wavelengths similar to aflatoxins, yielding false-positive results. In addition, the mycotoxin can occupy an inner region of the kernel, impairing detection by this method in intact corn kernels (Shotwell et al., 1974), causing false-negative results. Shotwell and
Hesseltine (1981) recommended grinding the sample as an alternative to avoid the false-negative results.

Total aflatoxin levels detected by spectrofluorimetry were higher than those obtained by TLC (Table 1). Aflatoxins were detected in 16 (40\%) corn samples by TLC, with levels ranging from 4.0 to $54.0 \mu \mathrm{g} / \mathrm{kg}$ (mean $19.97 \pm 15.97$ $\mu \mathrm{g} / \mathrm{kg})$, and in $25(62.5 \%)$ samples by spectrofluorimetry, with levels ranging from 1.0 to $58.66 \mu \mathrm{g} / \mathrm{kg}$ (mean $17.14 \pm 17.81 \mu \mathrm{g} / \mathrm{kg}$ ). Aflatoxin levels ranging from 1.0 to $20 \mu \mathrm{g} / \mathrm{kg}$ were detected in nine $(22.5 \%)$ samples by TLC and in $17(42.5 \%)$ samples by spectrofluorimetry, while levels ranging from 20.1 to $60.0 \mu \mathrm{g} / \mathrm{kg}$ were detected in seven $(17.5 \%)$ samples by TLC and 8 $(20.0 \%)$ by spectrofluorimetry. Considering 20 $\mu \mathrm{g} / \mathrm{kg}$ as the maximum limit allowed for total aflatoxins $\left(\mathrm{AFB}_{1}+\mathrm{AFB}_{2}+\mathrm{AFG}_{1}+\mathrm{AFG}_{2}\right)$ by the Brazilian Guidelines (ANVISA, 2002), 33 (82.5\%) and $32(80 \%)$ samples were adequate for consumption by TLC and spectrofluorimetry, respectively.

The spectrofluorimetry/TLC ratio values in 40 corn samples are shown in Table 2. Aflatoxins were not detected in 15 (37.5\%) samples by either method, while they were detected in nine $(22.5 \%)$ samples by spectrofluorimetry, but not by TLC probably due to the lower detection limit shown by spectrofluorimetry $(1.0 \mu \mathrm{g} / \mathrm{kg})$ compared to TLC $(4.0 \mu \mathrm{g} / \mathrm{kg})$. Aflatoxin levels detected by spectrofluorimetry were 1.1 to 1.5 fold higher than those detected by TLC in 8 (20\%) samples (Table 2 ), probably due to interferences in the matrix (Trucksses et al., 1991). The performance of immunoaffinity column methods depends on the antibody specificity (Patey et al., 1991).

Table 2 - Spectrofluorimetry/TLC (Thin-layer chromatography) ratio in 40 freshly harvested corn samples from the Northern region of Paraná State.

\begin{tabular}{ccc}
\hline Spectrofluorimetry/TLC ratio & $\mathbf{N}$ & \% \\
\hline n.d./n.d. & 15 & 37.5 \\
d/n.d. & 9 & 22.5 \\
$1.00-1.50$ & 8 & 20.0 \\
$1.51-3.00$ & 7 & 17.5 \\
$3.01-4.00$ & 1 & 2.5 \\
\hline
\end{tabular}

$\mathrm{N}=$ number of samples; n.d. $=$ not detected; $\mathrm{d}=$ detected.

The correlation between TLC and in naturally contaminated corn samples is shown spectrofluorimetry data for aflatoxin determination in Figure 1. The correlation coefficient $(\rho)$ of 0.97 
was similar to that reported by Nilüfer and Boyacioglu (2002), who evaluated aflatoxins spiked in tahini by HPLC and fluorometry ( $\rho=$ 0.98). Beaver et al. (1990) reported a high correlation coefficient $(\rho=0.99)$ analyzing 35 corn samples by postcolumn derivatization-liquid chromatography (LC-PCD) and TLC. The results (Fig. 1) indicated a good correlation between TLC and spectrofluorimetry demonstrating the effective use of spectrofluorimetry for aflatoxin determination in naturally contaminated corn. Nevertheless, the bright greenish-yellow fluorescence test showed $20 \%$ false-negative results, suggesting its use only as screening method for detecting the suspected lots of grains that should be tested further for aflatoxin by more sensitive methods.

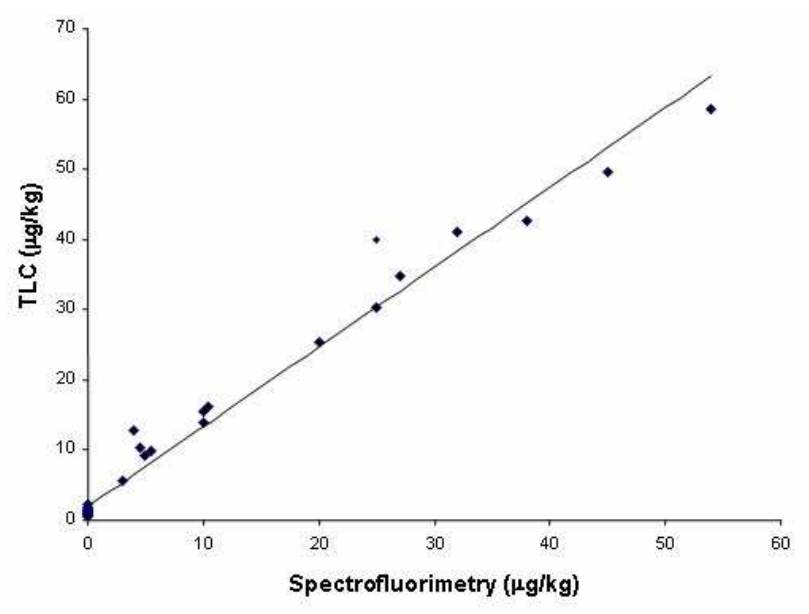

Figure 1 - Correlation between aflatoxin levels determined by TLC and spectrofluorimetry in naturally contaminated corn samples $(n=40)$. Linear regression equation $(y=1.1357$ $\mathrm{x}+1.9671)$ was obtained with correlation coefficient of 0.97 . $x$ and $y$ represent aflatoxin levels determined by spectrofluorimetry and TLC, respectively.

\section{ACKNOWLEDGEMENTS}

The authors thank the FINEP, CNPq (the Brazilian Government Organization for grant aid and fellowship to Brazilian researchers), the Araucária Foundation, Paraná Fund/SETI and CAPES (Coordination for Formation of High Level Professionals) for financial support. They are also grateful to ADETEC (Agency for Technological Development of Londrina city and Region) for interaction with regional food processing industries and project management, especially to Dr. Maria Victoria E. Grossmann and Dr. Plinio Pinto Mendonça Uchoa Jr.

\section{RESUMO}

Neste trabalho a contagem de fluorescência luminosa amarelo-esverdeada, amplamente utilizada pela indústria de processamento de milho, foi comparada à cromatografia em camada delgada (CCD) e espectrofluorimetria para detecção de aflatoxinas em 40 amostras de milho naturalmente contaminadas por Aspergillus section Flavi. De acordo com os critérios da indústria processadora de milho, todas as amostras estavam adequadas para o consumo humano e animal pela contagem de fluorescência luminosa amareloesverdeada (CFLAE), porém as análises por CCD e espectrofluorimetria detectaram aflatoxinas acima do limite máximo tolerado $(20 \mu \mathrm{g} / \mathrm{kg})$ em 7 e 8 amostras, respectivamente. As aflatoxinas foram detectadas em $16(40 \%)$ amostras por CCD, com níveis variando de 4,0 a $54,0 \mu \mathrm{g} / \mathrm{kg}$ (média $19,97 \pm 15,97 \mu \mathrm{g} / \mathrm{kg})$ e, em $25(62,5 \%)$ amostras por espectrofluorimetria, com níveis variando de 1,0 a $58,66 \mu \mathrm{g} / \mathrm{kg}$ (média $17,14 \pm 17,81 \mu \mathrm{g} / \mathrm{kg}$ ). Os resultados indicaram uma boa correlação $(\rho=0,97)$ entre CCD e espectrofluorimetria para detecção de aflatoxinas em amostras de milho naturalmente contaminadas. A CFLAE, apesar da simplicidade e rapidez, apresentou $20 \%$ de resultados falsonegativos, sugerindo seu uso apenas como método 
de triagem para detecção de lotes de grão suspeitos de contaminação que devem ser avaliados posteriormente por métodos mais sensíveis.

\section{REFERENCES}

Agência Nacional De Vigilância Sanitária (ANVISA), Brasil, 2002. Regulamento técnico sobre limites máximos de aflatoxinas admissíveis no leite, no amendoim, no milho, constante do anexo desta Resolução. Resolução RDC $\mathrm{n}^{\circ} 274$. Available from: <http://elegis.bvs.br/leisref/public/showAct.php?id=1 653\&word=> Accessed 2006 September 17.

Barna-Vetró, I.; Solti, L.; Téren, J.; Gyöngyösi, A.; Szabó, E. and Wölfling A. (1996), Sensitive ELISA test for determination of ochratoxin A. Journal of Agricultural and Food Chemistry, 44, 4071-4074.

Beaver, R.W.; Wilson, D.M. and Trucksess, M.W. (1990), Comparison of postcolumn derivatization liquid chromatography with thin-layer chromatography for determination of aflatoxins in naturally contaminated corn. Journal of the Association of Official Analytical Chemists, 73, 579581.

BRASIL. Portaria n.845 de 8 de novembro de 1976 Diário Oficial da República Federativa do Brasil. Brasília, 30 de novembro de 1976.

Gimeno, A. (1979), Thin-layer chromatographic determination of aflatoxins, ochratoxins, sterigmatocystin, zearalenone, citrinin, T-2 toxin, diacetoxyscirpenol, penicillic acid, patulin and penitrem. Journal of the Association of Analytical Chemists, 62, 579-585.

Glória, E. M.; Fonseca, H. and Souza, I. M. (1998), Ocurrence of mycotoxins in maize delivered to the food industry in Brazil. Food Additives and Contaminants, 15, 181-184.

Hussein, H. S. and Brasel, J. M. (2001), Review: Toxicity, metabolism and impact of mycotoxins on humans and animals. Toxicology, 167, 101-134.

Marsh, P. B.; Simpson, M. E.; Ferretti, R. J.; Merola, G. V.; Donoso, J.; Craig, G. O.; Trucksess, M. W. and Work, P. S. (1969), Mechanism of formation of a fluorescence in cotton fiber associated with aflatoxin in the seeds at harvest. Journal of Agricultural and Food Chemistry, 17, 468-472.

Nilüfer, D. and Boyacioglu, D. (2002), Comparative study of three different methods for the determination of aflatoxins in tahini. Journal of Agricultural and Food Chemistry, 50, 3375-3379.

Ono, E. Y. S.; Biazon, L.; Silva, M.; Vizoni, E.; Sugiura, Y.; Ueno, Y. and Hirooka, E. Y. (2006), Fumonisins in corn: Correlation with Fusarium sp. count, damaged kernels, protein and lipid content. Braz. Arch. Biol. Technol., 49, 63 - 71.
Palomino, M.E.T.; Fonseca, H.; Glória, E.M.; CaloriDomingues, M.A. and Marques, C. (1998), Avaliação do método de triagem para análise de milho contaminado com aflatoxinas pela fluorescência amarelo-esverdeada brilhante (BGYF- bright greenish yellow fluorescence). Scientia agrícola, 55, 503-508.

Patey, A.L.; Sharman, M. and Gilbert, J. (1991), Liquid chromatographic determination of aflatoxin levels in peanut butters using an immunoaffinity column cleanup method:International collaborative trial. Journal of the Association of Official Analytical Chemists, 74, 76-81.

Pestka, J.J.; Abouzied, M.N. and Sutikno. (1995), Immunological assays for mycotoxin detection. Food Technology, 2, 120-128.

Shotwell, O. L. and Hesseltine, C. W. (1981), Use of bright greenish yellow fluorescence as presumptive test for aflatoxin in corn. Cereal Chemistry. 58, 124127.

Shotwell, O. L.; Goulden, M. L. and Hesseltine, C. W. (1974), Aflatoxin: distribution in contaminated corn. Cereal Chemistry, 51, 492-499.

Soares, L. M. V. and Rodriguez-Amaya, D. B. (1989), Survey of aflatoxins, ochratoxins, zearalenone and sterigmatocystin in some Brazilian foods by using multi-toxin thin layer chromatographic method. Journal of the Association of Official Analytical Chemists International, 72, 22-26.

Sydenham, E.W.; Shephard, G.S.; Thiel, P.G.; Bird, C. and Miller, B.M. (1996a), Determination of fumonisins in corn: Evaluation of competitive immunoassay and HPLC techniques. Journal of Agricultural and Food Chemistry, 44, 159-164.

Sydenham, E.W.; Stockenstrom, S.; Thiel, P.G.; Rheeder, J.P.; Doko, M.B.; Bird, C. and Miller, B.M. (1996b), Polyclonal antibody-based ELISA and HPLC methods for the determination of fumonisins in corn: A comparative study. Journal of Food Protection, 59, 893- 897.

Thompson, C. and Henke, S. E. (2000), Effect of climate and type of storage container on aflatoxin production in corn and its associated risks to wildlife species. Journal of Wildlife Diseases, 36, 172-179.

Trucksess, M.W.; Stack, M.E.; Nesheim, S.; Page, S.W. and Albert, R.H. (1991), Immunoaffinity column coupled with solution fluorometry or liquid chromatography postcolumn derivatization for determination of aflatoxins in corn, peanuts, and peanut butter: Collaborative study. Journal of the Association of Official Analytical Chemists, 74, 8188.

WHO (World Health Organization). Mycotoxins. Geneva: UNEP/WHO, 1979, p.127.

Received: February 26, 2007; Revised: June 19, 2008; Accepted: July 02, 2009. 